\title{
SİSTEMİK RİSK, SİSTEMİK AÇIDAN ÖNEMLİ FİNANSAL KURULUŞLAR VE KÜRESEL FINANSAL KRİZ
}

\author{
Mehmet Mete KARADAĞ ${ }^{*}$
}

\begin{abstract}
Öz
2007'de ortaya çıkan ve hızla yayılan küresel finansal kriz, sistemik riskin finansal piyasalarda nasıl derin negatif etkilere yol açabileceğini ortaya koymuştur. Bu krizle birlikte, sistemik açıdan önemli finansal kuruluşlardan kaynaklanan sorunlar ve bunların ekonomilerde yol açabileceği zararlar daha belirgin bir hale gelmiştir. Finansal krizin ardından sistemik açıdan önemli finansal kuruluşların iflas olasılığını azaltmak ve başarısızlıklarının ekonomiler üzerindeki olumsuz etkilerini minimum düzeye çekebilmek için bu kuruluşlarla ilgili daha etkin bir gözetim ve denetim ihtiyacı hem ulusal hem de uluslararası finansal sistemin istikrarı için zorunlu bir hal almıştır. Batmayacak kadar büyük olarak algılanan bu finansal kuruluşlarla ilgili ahlaki risk ve sistemik risk problemlerini azaltmak ve piyasa disiplinini güçlendirmek amacı ile çeşitli ülkelerde düzenleyici ve denetleyici otoriteler birtakım düzenlemeler yapma ve kendi aralarında işbirliği oluşturma yoluna gitmişlerdir.

Bu çalışmada amaçlanan sistemik risk kavramı ve sistemik önemi oluşturan unsurları ele alarak sistemik açıdan önemli finansal kuruluşları değerlendirmeye yönelik yapılan çalışmaları incelemek; küresel finansal krizle ilgili olarak çeşitli ülkelerdeki "batmayacak kadar büyük" olarak algılanan finansal kuruluşların ortaya çıkardığ sistemik riske ve kurtarmalara değinerek sistemik riskin önlenmesine yönelik çalışmaların genel bir değerlendirmesini yapmaktır.
\end{abstract}

Anahtar Kelimeler: Sistemik Risk, Sistemik Açıdan Önemli Finansal Kuruluşlar, Sistemik Açıdan Önemli Bankalar, Batmayacak Kadar Büyük - Batmayacak Kadar Önemli, Küresel Finansal Kriz.

Jel Kodları: G01, G21, F65

\section{SYSTEMIC RISK, SYSTEMICALLY IMPORTANT FINANCIAL INSTITUTIONS, AND GLOBAL FINANCIAL CRISIS}

\footnotetext{
Abstract

The global financial crisis which has emerged in 2007 and rapidly spread, has revealed how deeply systemic risks can lead to negative effects on the financial markets. With this crisis, problems arising from

* Yrd. Doç. Dr., İstanbul Aydın Üniversitesi, metekaradag@aydin.edu.tr
} 
systemically important financial institutions and damages of these problems in the economy has become much more apparent. After the financial crisis, to reduce the likelihood of systemically important institutions' insolvency and to minimize the adverse effects of these institutions on the economy, the need for more effective supervision and oversight for the stability of both the national and international financial systems have become necessary. To reduce the moral hazard problems associated with these financial institutions -which were perceived as too big to fail- and the systemic risk, and to strengthen the market discipline in several countries regulatory and supervisory authorities have made some arrangements. They also attempted to establish collaboration among themselves.

This study aims to evaluate the concept of systemic risk and elements that make up systemic importance, to examine studies evaluating systemically important financial institutions. This study also focuses on bailouts and systemic risks stemming from financial institutions which perceived as "too big to fail" in several countries during the global financial crisis. It will be complemented with an overall assesment of the studies for the prevention of systemic risks.

Keywords: Systemic Risk, Systemically Important Financial Institutions, Systemically Important Banks, Too Big to Fail - Too Important to Fail, Global Financial Crisis.

Jel Codes: G01, G21, F65

\section{Giriş}

2007'de ortaya çıkan küresel finansal kriz ve bu krizin olumsuz etkileri, dikkatleri sistemik risk ve sistemik açıdan önemli finansal kuruluşlara yöneltmiştir. Büyülklügüu, karşılıklı bağlantıları ve karmaşıklığından ötürü iflası ya da sıkıntıya düşmesinin ekonomide önemli bozulma ve istikrarsızlıklara neden olabileceği finansal kuruluşlar olarak tanımlanan sistemik açıdan önemli finansal kuruluşlar, hem küresel hem de yerel düzeyde olabilmektedirler.

Küresel finansal krize yönelik çalışmalarda yetkili otoriteler sistemik açıdan önemli finansal kuruluşların saptanması ve bu kuruluşların finansal sisteme yönelik tehditlerinin ortadan kaldırılması için ulusal ve uluslararası düzeyde çalışmalar başlatmışlar ve işbirliğine gitmişlerdir.

Sistemik açıdan önemli finansal kuruluşlar sorun yaşadıklarında ve yükümlülüklerini yerine getiremeyecek derecede mali yapıları bozulduğunda yetkili otoriteler ve düzenleyiciler bir ikilemle karşılaşmaktadır: kurtarılmaları piyasa disiplinine zarar verebileceği ve risk almayı teşvik edebileceği gerekçesi ile sorunlu kuruluşun batmasına izin verilmelidir midir; yoksa battığı takdirde finansal sistemde daha fazla olumsuz etki yaratabileceği endişesi ile bu finansal kuruluşlar kurtarılmalı mıdır? Her iki görüşü de savunan taraflar mevcuttur.

Bu çalışmada öncelikle sistemik risk kavramı ile sistemik açıdan önemli finansal kuruluşlar ele alınacaktır. Ardından batmayacak kadar büyük ve batmayacak kadar önemli kavramları incelenerek, 2007-2009 küresel finansal krizi göz önünde bulundurularak bu kavramların genel bir değerlendirmesi yapılacaktır. Son olarak ise sistemik öneme sahip kuruluşlar ve Türkiye konusuna değinilecektir. 


\section{SISTEMIK RISK KAVRAMI VE SISTEMIK AÇIDAN ÖNEMLI FINANSAL KURULUŞLAR}

Sistemik önemi oluşturan unsurları saptamak güçtür ve çoğu G-20 ülkelerinde her ne kadar resmi bir tanımı olmasa da uygulamada, "iflası ya da bozulmasının doğrudan ya da dolaylı olarak bir bulaşmayı tetiklediği geniş çaplı sıkıntılara yol açan bir kuruluş, piyasa ya da enstrüman sistemik olarak kabul edilmektedir" (BIS-IMF-FSB, 2009, 5).

European Central Bank (ECB), sistemik riski “finansal istikrarsızlığın çok fazla yaygınlaşarak ekonomik büyüme ve refahın maddi olarak zarar görecek kadar finansal sistemin işleyişinin bozulması riski” olarak tanımlanmaktadır (European Central Bank, 2009, 134).

Financial Stability Board (FSB), International Monetary Fund (IMF) ve Bank for International Settlements (BIS) tarafından hazırlanan 2009 tarihli raporda sistemik risk (BIS-IMF-FSB, 2009, 2-13): “(i) finansal sistemin tamamında ya da bir kısmında bozulmalardan kaynaklanan ve (ii) reel ekonomi için ciddi negatif sonuç potansiyeline sahip olan finansal hizmetlerde bozulma riski” olarak tanımlanmaktadır ve her tür finansal aracı, piyasa ve altyapının potansiyel olarak belirli bir dereceye kadar sistemik açıdan önemli olabileceği ifade edilmektedir. Aynı raporda piyasa ve kurumların sistemik öneminin belirlenmesinde üç temel kriterin yardımcı olacağ belirtilmektedir: “i.büyüklük (finansal sistemin tek bir unsuru tarafından sağlanan finansal hizmet miktarı), ii.ikame (başarısızlık durumunda sistemin hangi diğer unsurlarının aynı hizmetleri sağlayabileceği) ve iii.karşılıklı bağlantılar (sistemin diğer unsurlarıyla bağlantılar)”. Sistemik önemin değerlendirilmesinde üç ana kritere ilave olarak bazı spesifik ya da ekonomi genelinde faktörler ise: "kaldıraç", "büyük vade uyuşmazlıkları ile likit olmayan aktifler tutma" ve "karmaşıklık" olarak ifade edilmektedir.

FSB tarafından yapılan tanımda sistemik açıdan önemli finansal kuruluşlar (systemically important firms); "büyüklüğü, karmaşıklı̆̆ı ve sistemik açıdan karşılıklı bağlantılarından ötürü sıkıntıya düşmesinin ya da düzensiz iflasının finansal sistem ve ekonomik aktivite üzerinde çok büyük bozulmalara yol açabildiği finansal kuruluşlar” olarak tanımlanmaktadır (Financial Stability Board, 2011, 1).

Bir firmanın neden sistemik açıdan önemli olabileceğini anlamak suretiyle sistemik açıdan önemli firma sayısını azaltmak için gerekli tedbirler alınabilir ve en düşük maliyetle bu tür firmaların başarısızlıklarının çözümlenmesine yönelik yöntemler geliştirilebilir (Thomson, James B., 2010, 136).

G-20 Liderleri 2010 yılında FSB'den sistemik öneme sahip finansal kuruluşlar ile ilişkili sistemik ve ahlaki tehlike risklerini gidermek için bir politika çerçevesi geliştirmelerini istemiştir. G-20 liderleri bu çerçeveyi ve uygulanması için zaman çizelgelerini ve süreçlerini onaylamıştır. $\mathrm{Bu}$ çerçevenin parçalarını oluşturan kritik politika tedbirlerinin geliştirilmesi tamamlanmıştır. $\mathrm{Bu}$ tedbirlerin uygulanmasına 2012'de başlanması tamamen uygulanması için ise 2019 yılı hedeflenmiştir (Financial Stability Board, 2011, 1).

20 Ekim 2010'da yayınlanan FSB tarafından hazırlanan raporda sistemik açıdan önemli finansal kuruluşlarla ilgili ahlaki riskin ve sistemik riskin azaltılmasına ilişkin öneriler yer almaktadır. Bu Raporda öncelikle ahlaki riski azaltmak için genel politika çerçevesi açılanmakta, 
hayati ekonomik fonksiyonların devamlılı̆̆ını korurken vergi mükelleflerinin üzerine zararları yüklemeksizin sistemik açıdan önemli finansal kuruluşların çözümlenmesi için otoritelerin olanaklarının geliştirilmesi gerektiği belirtilmekte ve aşağıdaki maddeler halinde öneriler siralanmaktadır (Financial Stability Board, 2010, 1-12):

- küresel sistemik açıdan önemli finansal kuruluşlar daha yüksek zarar karşılama gereğine sahip olması

- Sistemik açıdan önemli finansal kuruluşların çözümlenmesinin uygun bir seçenek olması

- sistemik açıdan önemli finansal kuruluşların denetiminin güçlendirilmesi

- temel finansal altyapıların güçlendirilmesi

- küresel sistemik açıdan önemli finansal kuruluşlar için etkili ve tutarlı ulusal politikaların uygulanmasının sağlanması.

\section{I. Küresel Olarak Sistemik Açıdan Önemli Bankalar}

Basel Komitesi tarafından küresel sistemik açıdan önemli bankaları değerlendirme metodolojisi ve ek zarar karşılama gereği ile ilgili belge Kasım 2011'de yayınlanmıştır (Basel Committee on Banking Supervision, 2011). Basel Committee on Banking Supervision (BCBS) ve FSB, bu belgede yer alan metodolojiye dayanarak küresel olarak sistemik açıdan önemli 29 bankayı belirlemiş ve listelemişlerdir. Listenin her yıl güncellenerek kasım aylarında FSB tarafından yayınlanması kararlaştıılmıştır. BCBS’nin metodolojisi bankacılık sistemindeki değişiklikler ve sistemik riskin öneminin ölçülmesindeki gelişmeler doğrultusunda için her üç yllda bir yeniden gözden geçirilecektir. Listedeki kuruluşlar zaman içinde değişebilecek, bazı kuruluşlar liste dışına çıkarılırken yeni kuruluşlar listeye eklenebilecektir (Financial Stability Board, 2011, 4).

FSB tarafindan 2011 Kasım Ayında yayınlanan listede yer alan bankalar Tablo: 1'de yer almaktadir:

Tablo I. Küresel Olarak Sistemik Açıdan Önemli 29 Banka

\begin{tabular}{|l|l|}
\hline Bank of America & JP Morgan Chase \\
Bank of China & Lloyds Banking Group \\
Bank of New York Mellon & Mitsubishi UFJ FG \\
Banque Populaire CdE & Mizuho FG \\
Barclays & Morgan Stanley \\
BNP Paribas & Nordea \\
Citigroup & Royal Bank of Scotland \\
Commerzbank & Santander \\
Credit Suisse & Société Générale \\
Deutsche Bank & State Street \\
Dexia & Sumitomo Mitsui FG \\
Goldman Sachs & UBS \\
Group Crédit Agricole & Unicredit Group \\
HSBC & Wells Fargo \\
ING Bank & \\
\hline
\end{tabular}

Kaynak: Financial Stability Board (2011), "Policy Measures to Adress Systemically Important financial Institutions", http://www.financialstabilityboard.org/publications/r_111104bb.pdf, s.4, (Erişim: 8 Mart 2012). 
BCBS ve FSB tarafından 6 Kasım 2014’te Küresel Olarak Sistemik Açıdan Önemli Banka listesi yenilenmiştir. Bu yeni listeye Agricultural Bank of China bankası ilave edilmiştir (Financial Stability Board, 2014b, 3).

Basel Komitesi, sistemik önemin iflas riskinin gerçekleşmesi açısından ziyade bir banka iflasının küresel finansal sistem ve geniş çaplı ekonomi üzerinde yaratabileceği etkisi bakımından ölçülmesi gerektiği görüşündedir. Komite’nin küresel olarak sistemik açıdan önemli bankaların sistemik öneminin değerlendirilmesi için geliştirdiği metodoloji, gösterge-tabanlı ölçüm yaklaşımına dayanmaktadır. Belirlenen göstergeler negatif dışsallıkları nelerin yarattığının ve bankaları finansal sistemin istikrarı açısından kritik bir hale nelerin getirdiğinin farklı boyutlarını yansıtacak şekilde seçilmiştir. Seçilen göstergeler bankaların büyüklüklerini, onların karşılıklı bağlantılarını, bankaların sağladıkları hizmetler için mevcut ikamelerinin ya da finansal kuruluş altyapısının eksikliğini, küresel faaliyetleri (sınır ötesi faaliyetler) ve karmaşıklı̆̆ı yansıtmaktadır. Sistemik önemin değerlendirilmesi için geliştirilen metodoloji beş sistemik önem kategorisinin her birine \%20 eşit ağıtlık vermektedir. Bunlar: büyüklük, sınır ötesi faaliyet, karşılıklı bağlılık, ikame edilebilirlik/finansal kurum altyapısı ve son olarak "karmaşıklık”'ır. Basel Komite, kategorilerin içindeki çoklu göstergeleri belirlemiştir. Her gösterge kendi kategorisi içinde eşit olarak ağırlıklandırılmıştır. Eğer bir kategoride iki gösterge varsa her bir göstergeye \%10 toplam ağırlık verilirken üç gösterge olan kategorilerde her göstergeye \%6.67 ağırlık verilmiştir (Basel Committee on Banking Supervision, 2013, 5-6). Gösterge ölçüm yaklaşımı Tablo: 2'de yer almaktadır:

Tablo 2. Gösterge-Tabanlı Ölçüm Yaklaşımı

\begin{tabular}{|c|c|c|}
\hline Kategori ve Ağırlık & Göstergeler & Gösterge Ağırlı̆̆ı \\
\hline \multirow[b]{2}{*}{ Sınır Ötesi Faaliyet (20\%) } & Sinır ötesi alacaklar & $\% 10$ \\
\hline & Sınır ötesi borçlar & $\% 10$ \\
\hline Büyüklük (20\%) & $\begin{array}{l}\text { Basel III kaldıraç oranında tanımlandığı gibi } \\
\text { Toplam riskler }\end{array}$ & $\% 20$ \\
\hline \multirow{3}{*}{ Karşılıklı bağlantılılık (20\%) } & Finansal sistemden alacaklar & $\% 6.67$ \\
\hline & Finansal sisteme borçlar & $\% 6.67$ \\
\hline & Dolanımdaki menkul kıymetler & $\% 6.67$ \\
\hline \multirow{3}{*}{$\begin{array}{l}\text { İkame Edilebilirlik/finansal } \\
\text { kurum altyapısı }(20 \%)\end{array}$} & Emanettteki Kıymetler & $\% 6.67$ \\
\hline & Ödeme Faaliyeti & $\% 6.67$ \\
\hline & $\begin{array}{l}\text { Borç ve sermaye piyasalarında yüklenim yapılan } \\
\text { işlemler }\end{array}$ & $\% 6.67$ \\
\hline \multirow{3}{*}{ Karmaşıklık (20\%) } & Tezgah üstü türev tutarı & $\% 6.67$ \\
\hline & Üçüncü düzey aktifler & $\% 6.67$ \\
\hline & İşlem gören ve satılmaya hazır menkul kıymetler & $\% 6.67$ \\
\hline
\end{tabular}

Kaynak: Basel Committee on Banking Supervision (2013), "Global systemically important banks: updated assessment methodology and the higherloss absorbency requirement", http://www.bis.org/publ/bcbs255. pdf, s.6, (Erişim: 21.02.2014). 
Gösterge-tabanlı ölçüm yaklaşımına göre hesaplanmış skora sahip bankalardan Basel Komitesi tarafından belirlenen bir düzeyi aşanlar Küresel Olarak Sistemik Açıdan Öneme Sahip Banka olarak sınıflandırılacaklardır. İlk aşamada küresel olarak sistemik açıdan öneme sahip bankalar, sistemik önem skorlarına dayalı dört eşit büyüklükteki gruba yerleştirileceklerdir. Her bir gruba yönelik farklı seviyelerde daha yüksek zarar karşılama gereği uygulanmaktadır. Grup eşikleri sabitlendikten sonra, eğer bir bankanın skoru dördüncü grubun üst eşiğini aşarsa bankayı yerleştirmek için yeni gruplar eklenecektir. Bankalara sistemik açıdan önemli olmaktan kaçınmalarına yönelik teşvikler sağlamak için bu yeni gruplarda daha yüksek zarar karşılama gereği oranları artacaktır. Daha yüksek zarar karşılama gereğinin büyüklüğü en yüksek grup için risk ağırlıklı aktiflerin \%2.5 kadarı olacaktır. Başlangıçta \%3.5 risk ağırlıklı aktiflerin olduğu boş bırakılan beşinci bir grup olacaktır. En düşük grup için daha yüksek zarar karşılama gereği risk ağırlıklı aktiflerin \%1.0’ı kadar olacaktır. Daha yüksek zarar karşılama gereği Basel 3 taslağında tanımlanan 1. kuşak çekirdek sermaye ile karşılanacaktır (Basel Committee on Banking Supervision, 2013, 8-12). Her grup için daha yüksek zarar karşılama gereğinin büyüklüğü Tablo: 3’teki gibidir:

Tablo 3. Gruplandırma Yaklaşımı

\begin{tabular}{|c|c|c|}
\hline Gruplar & Skor Aralığı* & $\begin{array}{l}\text { Daha yüksek zarar karşılama gereği } \\
\text { (risk ağırlıklı aktiflerin yüzdesi } \\
\text { olarak çekirdek sermaye }\end{array}$ \\
\hline 5 & D-E & $\% 3.5$ \\
\hline 4 & C-D & $\% 2.5$ \\
\hline 3 & $\mathrm{~B}-\mathrm{C}$ & $\% 2.0$ \\
\hline 2 & $A-B$ & $\% 1.5$ \\
\hline 1 & Kesim Noktası A & $\% 1.0$ \\
\hline
\end{tabular}

Kaynak: Basel Committee on Banking Supervision (2013), “Global systemically important banks: updated assessment methodology and the higherloss absorbency requirement”, http://www.bis.org/publ/bcbs255. pdf, s.12, (Erişim: 21.02.2014)

Kasım 2014 itibariyle gruplara dağıtılan Küresel Açıdan Önemli Bankalar Tablo: 4’te yer almaktadır: 
Tablo 4. Kasım 20 I 4 İtibariyle Gruplara Dağıtılan Küresel Açıdan Önemli Bankalar

\begin{tabular}{|c|c|}
\hline Grup & Her Grup İçindeki Küresel Açıdan Önemli Bankalar \\
\hline $\begin{array}{l}5 \\
(3.5 \%)\end{array}$ & - \\
\hline $\begin{array}{l}4 \\
(2.5 \%)\end{array}$ & $\begin{array}{l}\text { HSBC } \\
\text { JP Morgan Chase }\end{array}$ \\
\hline $\begin{array}{l}3 \\
(2.0 \%)\end{array}$ & $\begin{array}{l}\text { Barclays } \\
\text { BNP Paribas } \\
\text { Citigroup } \\
\text { Deutsche Bank }\end{array}$ \\
\hline $\begin{array}{l}2 \\
(1.5 \%)\end{array}$ & $\begin{array}{l}\text { Bank of America } \\
\text { Credit Suisse } \\
\text { Goldman Sachs } \\
\text { Mitsubishi UFJ FG } \\
\text { Morgan Stanley } \\
\text { Royal Bank of Scotland }\end{array}$ \\
\hline $\begin{array}{l}1 \\
(1.0 \%)\end{array}$ & $\begin{array}{l}\text { Agricultural Bank of China } \\
\text { Bank of China } \\
\text { Bank of New York Mellon } \\
\text { BBVA } \\
\text { Groupe BPCE } \\
\text { Group Crédit Agricole } \\
\text { Industrial and Commercial Bank of China Limited } \\
\text { ING Bank } \\
\text { Mizuho FG } \\
\text { Nordea } \\
\text { Santander } \\
\text { Société Générale } \\
\text { Standard Chartered } \\
\text { State Street } \\
\text { Sumitomo Mitsui FG } \\
\text { UBS } \\
\text { Unicredit Group } \\
\text { Wells Fargo State Street } \\
\text { Sumitomo Mitsui FG } \\
\text { Unicredit Group } \\
\text { Wells Fargo }\end{array}$ \\
\hline
\end{tabular}

Kaynak:Financial Stability Board (2014b), “2014 Update of List of Global Systemically Important Banks (G-SIBs)”, http://www.financialstabilityboard.org/wp-content/uploads/r_141106b.pdf, s.2 (Erişim:

03.03.2014). 


\subsection{Yerel Olarak Sistemik Açıdan Önemli Bankalar}

Uluslararası açıdan önemli olmayan ancak sistemik olmayan kuruluşlarla kıyaslandığında yurtiçi finansal sistem ve ekonomi üzerinde önemli etkileri olabilecek çok sayıda banka mevcuttur. Etkileri doğasında küresel olmasa da bu bankaların bazılarının sınır ötesi dışsallıkları olabilmektedir. Bu açıdan G-20 Liderleri, Basel Komitesi ve FSB'den "Küresel Sistemik Açıdan Önemli Bankalar" çerçevesini "Yerel Sistemik Açıdan Önemli Bankalara" (Domestic Systemically Important Banks) genişletmelerini istemiştir. Bununla ilgili olarak BCBS tarafından Ekim 2012'de "A Framework For Dealing With Domestic Systemically Important Banks" başlıklı bir belge yayınlanmıştır. Bu belgeye göre, Basel Komitesi, Yerel Sistemik Açıdan Önemli Banka çerçevesini teşkil eden 12 prensip oluşturmuştur. Bu prensipler iki gruba ayrılmıştır. Birinci grup bu bankalara yönelik değerlendirme metoduna odaklanırken; ikinci grup, bu bankalar için daha yüksek zarar karşılama gereğine odaklanmıştır. Yerel sistemik açıdan önemli bir bankanın başarısızlı̆̆ının yerel ekonomi üzerindeki etkisi bankaya özgü "büyüklük", "karşıllklı bağllık", "ikame edilebilirlik/ finansal kurum altyapısı" ve "karmaşıklı" faktörlerine göre değerlendirilebilmektedir. Bu faktörlere ilave olarak ulusal otoriteler yurtiçi ekonominin büyüklüğü gibi diğer verilerden de yararlanabilirler ayrıca ulusal otoriteler, banka büyüklüğünün gayri safi yurt içi hasılaya oranı gibi bazı ülkeye özgü faktörleri de kullanabilirler (Basel Committee on Banking Supervision, 2012, 1-6).

\subsection{Küresel Olarak Sistemik Açıdan Önemli Sigorta Kuruluşları}

Küresel ve yerel olarak sistemik açıdan önemli bankalar dışında "sigorta kuruluşları" ve "banka ve sigorta dışı" kuruluşlar da sistemik öneme sahip olabilirler. Bu açıdan sistemik açıdan önemli sigorta kuruluşlarının ve sistemik açıdan önemli banka ve sigorta dışı kuruluşları değerlendirme yöntemlerine ilişkin çalışmalar da yürütülmektedir.

18 Temmuz 2013 tarihinde the International Association of Insurance Supervisors (IAIS) tarafından küresel sistemik açıdan önemli sigorta kuruluşlarını tanımlamaya ve onlara uygulanabilecek politika tedbirlerine yönelik bir metodoloji yayınlanmıştır. $\mathrm{Bu}$ kuruluşları değerlendirme metodolojisi, Basel komitesi tarafından küresel sistemik açıdan önemli bankalar için geliştirilen gösterge tabanlı değerlendirme metodolojisine benzemektedir. Bu metodolojide yararlanılan göstergeler: "büyüklük", "küresel aktiviteler", "karşılıklı bağlantılar", "geleneksel olmayan ve sigorta dışı aktiviteler" ve "ikame edilebilirilik"tir (International Association of Insurance Supervisors, 2013, 12). FSB bu metodolojiyi ve politik tedbirlerini onaylamış ve IAIS metodolojisinden ve 2011 yllına ilişkin verilerden yararlanarak 9 adet Küresel Olarak Sistemik Açıdan Önemli Sigorta kuruluşu tespit etmiştir. Bu kuruluşların listesi yıllık olarak güncellenerek Kasım 2014’ten başlayarak yeni verilere dayalı olarak FSB tarafından her Kasım ayında yayınlanması planlanmıştır (Financial Stability Board, 2013a, 1-4).

FSB tarafından Temmuz 2013 itibariyle yayınlanan listede yer alan kuruluşlar Tablo: 5’te yer almaktadır: 


\title{
Tablo 5. Küresel Olarak Sistemik Açıdan Önemli Sigorta Kuruluşları
}

\author{
Allianz SE \\ American International Group, Inc. \\ Assicurazioni Generali S.p.A. \\ Aviva plc \\ Axa S.A. \\ MetLife, Inc. \\ Ping An Insurance (Group) Company of China, Ltd. \\ Prudential Financial, Inc. \\ Prudential plc
}

Kaynak: Financial Stability Board (2013a), "Global systemically important insurers (GSIIs) and the policy measures that will apply to them", http://www.financialstabilityboard.org/publications/r_130718.pdf, ss.1-

4 (Erişim: Mart 2014).

FSB tarafından Temmuz 2013'te yayınlanan listenin ardından 6 Kasım 2014'te güncellenmiş yeni bir liste yayınlanmıştır ancak yeni listede önceki yıla göre herhangi bir değişiklik olmadığı görülmektedir (Financial Stability Board, 2014a, 2).

Kasım 2011 tarihinde G-20 Liderleri FSB'den, IOSCO’ya danışarak sistemik açıdan önemli banka ve sigorta dışı finansal kuruluşları tanımlamak için yöntemler geliştirmesini istemiştir. Bununla ilgili olarak 8 Ocak 2014 tarihinde FSB tarafından bir rapor yayınlanmıştır. Bu raporda "finans şirketleri”, "piyasa aracıları (menkul kıymet broker ve dealer'ları)" ve "yatırım fonları (hedge fonlar dahil)" için banka ve sigorta dışı finansal sektöre özgü detaylı metodolojiler tanımlanmıştır (Financial stability Board and IOSCO, 2014, 1-2).

\section{BATMAYACAK KADAR BÜYÜK - BATMAYACAK KADAR ÖNEMLI UYGULAMALARI VE KÜRESEL FINANSAL KRIZ}

Büyük ve karmaşık finansal kuruluşların olası iflasının bir domino etkisine ve/ya da bir sistemik riske neden olmasından endişe edilmektedir. Bu durum karşısında "kamu müdahaleleri sayesinde büyük finansal kuruluşların batmasına izin verilmemesi olarak ifade edilebilen" batmayacak-kadar-büyük olgusu ortaya çıkabilmektedir (Ito, 211, 562). Enis ve Malek'e göre "Batmayacak kadar büyük" inancının ardında yatan düşünce, sistemik öneme sahip olduğu düşünülen yani olası iflasının tüm finansal sistemin istikrarını tehdit edebildiği kuruluşların genellikle karar alıcılar tarafından kurtarılmaya eğilimli olmalarıdır (Enis and Malek, 2005, 21). 
Büyük kuruluşların batmasına izin verilmediği örtülü ya da açık kamu garantileri piyasa disiplinine zarar verebilmekte ve ilgili tarafların bu tür kuruluşların batmasına göz yumulmayacağını düşünerek daha fazla risk almalarına, alacaklıların, müşterilerin ve yatırımcıların bu kuruluşları izlemelerine yönelik teşviklerinin azalmasına yol açabilmektedir. Batmasına müsaade edilmeyeceğine inanan finansal kuruluşlar, küçük rakiplerine karşı avantaj sağlayabilmektedir. Derecelendirme kuruluşları da örtülü hükümet garantilerinin varlığına dayanarak bu kuruluşlara yüksek kredi notları verebilmektedir (SIGTARP, 2011, 6-7).

Moodys'e göre 2009'da 50 büyük bankaya resmi destek sağlanması bu kuruluşların reytingini 2006'deki iki basamak artıştan (A1'den Aa2'ye) daha yüksek bir artışla, ortalama 3 basamak artı̧̧a dönüştürmüştür (A3’ten Aa3’e) (BIS, 2010, 79). Bu durum batmayacak kadar büyük kuruluşların bunun avantajlarından yararlanmasına ve rekabete zarar vermesine bir örnek olarak gösterilebilir.

"Batmayacak kadar büyük" terimi ile ilgili olarak altı çizilmesi gereken bir nokta, sistemik açıdan önemli kuruluşların önemli olmasının tek kriterinin "büyüklük" olmadığıdır (Enis and Malek, 2005, 21); ancak literatürde yaygın olarak kullanılan ifade "batmayacak kadar büyük" şeklindedir. Batmayacak kadar büyük olarak düşünülen bir kuruluşun "batmayacak kadar önemli” (too-important-to fail) olduğunu da göz önünde bulundurmak gerekmektedir.

Chow ve Surti’ye göre: "büyüklükleri, karşılıklı bağlantıları ya da karmaşıklıklarından ötürü sistemik açıdan önemli finansal kuruluşların finansal sıkıntılarından kaynaklanan negatif dışsallıklar bu kuruluşları bir sistemik risk kaynağı haline getirmektedir ki bu durum onların batmayacak kadar önemli olarak varsayılmalarına yol açmaktadır" (Chow and Surti, 2011, 3).

\section{I. Küresel Finansal Kriz ve Kurtarma Örnekleri}

ABD'de konut fiyatları balonunun patlamasıyla ortaya çıkan kriz pek çok bankanın batmasına, bazı büyük bankaların da devlet tarafından kurtarılmasına yol açmıştır. Kriz kısa sürede diğer ülkelere de sıçrayarak küresel bir hal almıştır. Pek çok ülkede yetkili otoriteler, banka gibi finansal kurumların kurtarılması için birtakım tedbirler almak zorunda kalmışlardır.

Ülkeler kriz esnasında finansal sistemi desteklemek için önemli miktarlarda kamu kaynağını sisteme aktarmışlardır. Örneğin G-20 ülkelerinde hükümetlerin finansal sisteme yönelik doğrudan desteklerinin finansal maliyeti GSYİH'larının ortalama \%2.8'ini bulmuştur (Claessens, Keen and Pazarbasioglu, 2010, 2)

"Ahlaki risk, bir işlemde taraflardan birinin işlemin riskini tamamen dikkate aldığı durumdan daha farklı hareket etmesi riski" olarak tanımlanabilir (Financial Stability Oversight Council, 2011, 10). Son dönemlerde yaşanan küresel finansal krizin görülmemiş kapsam ve şiddeti batmayacak kadar önemli olarak görülen sistemik açıdan önemli finansal kuruluşlarla ilişkili ahlaki risk problemlerini gündeme getirmiştir (Ötker-Robe vd., 2011, 2-3). Bu krizde "batmayacak kadar büyük" ya da "batmayacak kadar önemli" olduğu kabul edilen finansal kuruluşlara yönelik geniş çaplı devlet desteği yüksek maliyetli olmuş ve potansiyel olarak ahlaki riski artırmıştır (Zhou vd., 2012, 3). Kriz öncesinde örtülü devlet destekleri bu kuruluşların yeterince piyasa disiplinine maruz kalmaksızın aşırı risk almalarını ve sistemik açıdan daha az önemli kuruluşlar karşısında 
rekabet avantajına sahip olmalarını sağlamıştır (Ötker-Robe vd., 2011, 2-3).

Aşağıda küresel finansal kriz esnasında bazı ülkelerdeki finansal kuruluşlarla ilgili batmayacak kadar büyük durumları ve kurtarmalara ilişkin saptamalar yer almaktadır:

\section{A.B.D.}

A.B.D.de Hazine, Federal Reserve ve diğer düzenleyiciler zor durumdaki ya da iflas etmiş ödeme aczine düşmüş büyük kuruluşlar için kurtarma ve birleştirme planları oluşturmuşlardır. $\mathrm{Bu}$ kuruluşlar arasında Fennie Mae, Freddie Mac, Bear Stearns, WaMu, Wachovia, AIG, Countrywide ve Merrill Lynch yer almaktadır; ancak Lehman Brothers gibi diğer kuruluşların batmasına müsaade edilmiştir (Hoenig, 2009, 4).

Dünyanın en büyük finansal kuruluşlarından biri olan yatırım bankası Bearn Stearns'ün finansal durumu Ocak 2008 ortası ve Mart 2008 ortası aralığında belirgin şekilde bozulmuştur. Bearn Stearns 13 Mart 2008'de Federal Reserve'e ertesi gün finansal yükümlülüklerini karşılayabilecek yeterli kaynağa ya da likit aktiflere sahip olamayacağını ve özel sektör alternatif finansman kaynağı bulamayacağını bildirmiştir (Board of Governors of the Federal Reserve System, 2014).

Karşı taraflarla yaklaşık 150 milyon karşılıklı işleme sahip olduğu için Bear Stearns, ansızın batmasına izin verilemeyecek kadar çok bağlantılı olduğu kabul edilmiştir (Brunnermeier, 2009, 88). Bear Stearns'ün iflasının yakında gerçekleşmesinin beklenmesi, finansal piyasalardaki büyük ölçekli varlığı ve benzer durumdaki firmalara sorunun bulaşma riski; eğer Bear Stearns finansal ilişkide bulunduğu taraflara karşı ansızın yükümlülüklerini yerine getiremez bir duruma düşerse, finansal piyasalardaki istikrarın önemli ölçüde bozulacağına dair endişelerin oluşmasına yol açmıştır ve Bear Stearns'ün düzenli çözümlenmesi için kaynak aktarılmıştır. Bearn Stearns'ün ani likidite ihtiyacına yanıt vermek ve ödeme aczine düşmesi ya da iflasının zaten gerilimli kredi piyasalarında potansiyel sistemik bozulmaları engellemek için 14 Mart 2008'de Federal Reserve Board, JPMorgan Chase Bank vasıtasıyla kredi aktarılması için Federal Reserve Bank of New York’a yetki vermiştir. Federal Reserve'ün desteğine rağmen Bear Stearns üzerindeki baskılar atmış; 16 Mart 2008 tarihinde Bear Stearns JPMorgan Chase ile birleşme teklifini kabul etmek zorunda kalmıştır (Board of Governors of the Federal Reserve System, 2014). Hoenig'e göre Bear Stearns'ün satışı, büyük finansal kuruluşlar sorunlarla karşılaştıklarında bir kriz durumunda kamu otoritelerinin piyasa disiplinin bozulmasına izin vermeyecek bir konumda olacaklarını gösteren bir örnektir. Bear Stearns'ün çöküşü, "sistemik açıdan önemli” ve "batmayacak kadar büyük” gibi ifadelerin üst katmanın altında olan yatırım bankaları için de uygulanabildiğini göstermektedir (Hoenig 2008, 9).

Fanie Mae (Federal National Mortgage Association) ve Freddie Mac'e (Federal Home Loan Mortgage Corporation) ABD’de İpotekli konut finansmanı piyasasında yer alan, konut piyasasına destek sağlanması amacı ile oluşturulan devlet destekli iki kuruluştur. Fanie Mae ve Freddie Mac konut piyasasında ve finansal piyasalarda önemli bir ağırlığa sahip olduklarından, piyasalarda, finansal güçlüğe düştükleri takdirde bu iki kurumun otoriteler tarafından batmasına müsaade 
edilmeyerek kurtarılacağı şeklinde bir kanı oluşmuştur; ancak ABD hükümetinin açıklamasına göre Fannie Mae’nin ve Freddie Mac'in finansal durumu öylesine bozulmuştur ki, piyasa için ciddi bir tehdit haline gelmiştir ve 7 Eylül 2008'de ABD hükümeti tarafından bu kuruluşlara el konulmuştur (Bkz. Brunnermeier, 2009, 89).

Merrill Lynch yatırım bankası 14 Eylül 2008'de Bank of America'ya satılmıştır. Bir başka büyük yatırım bankası Lehman Brothers, 15 Eylül 2008'de iflasını istemiştir (Brunnermeier, 2009, 89). Lehman Brothers'ın hükümet tarafından kurtarılmaması "batmayacak kadar büyük" anlayışı hakkında birtakım soru işaretlerinin oluşmasına yol açmıştır. Lehman Brothers FED'den yardım almamış; oysa Bearn Stearns almıştır.

Lehman Brothers'in çöküşü bankalardaki mevduat sahipleri ve para piyasası fonları arasında bir güven krizine yol açmıştır ki bu durumun piyasalar üzerinde önemli etkileri olmuştur (Bebechuk, 2009). Lehman Brothers’ın batışından kısa bir süre sonra 10 Ekim 2008'de G-7 ülkelerinin finans bakanları ve merkez bankası guvernörleri Washington'da bir araya gelmişler ve sistemik açıdan önemli finansal kuruluşları desteklemek ve iflaslarını önlemek için gerekli adımları atmak ve eldeki tüm araçları kullanmak konusunda görüş birliğine varmışlardır. Birkaç gün sonra ise Avrupa Birliği liderleri 15-16 Ekim 2008 Avrupa Konseyi toplantısında finansal sistemin istikrarını sağlamak, büyük finansal kuruluşları desteklemek, iflasları engellemek ve tasarruf sahiplerinin mevduatlarını korumak için gerekli tedbirlerin alınacağını açıklamışlardır (Goldstein and Véron, 2011, 2).

FDIC Başkanı Sheila C. Bair, Lehman alacaklıları için uzun vadeli sonucunun batık finansal şirketleri çözmek için bir araç olarak iflasın eksikliklerini açıkça gösterdiğini açıklamıştır. 75 milyar dolardan fazla değer iflas sürecinin kendisi tarafından yok edilmiştir. Lehman’ın iflasının ardından geçen iki buçuk yıldan uzun bir süre sonra süreç 1.2 milyar dolardan fazla maliyete neden olmuştur (Bair, 2011, 26).

Lehman Brothers’ın iflasının ardından sigorta devi AIG’nin iflas edeceği konuşulmaya başlanmış ve olası iflasının piyasalarda büyük negatif etkilere yol açacağı düşünülen AIG, Amerikan Hükümeti tarafından batmayacak kadar büyük olduğuna karar verilerek kurtarılmıştır.

25 Eylül 2008'de Washington Mutual'a FDIC tarafindan el konulmuştur. Washington Mutual’ın varlıklarını ve çoğu yükümlülüğü JPMorgan tarafından alınmıştır (FDIC, 2008). Bir başka finansal kuruluş olan Wachovia, 31 Aralık 2008'de Wells Fargo \& Company tarafindan satın alınmıştır (Wells Fargo, 2009).

Federal Reserve eski başkanı Alan Greenspan New York’taki bir konuşmasında ABD'deki düzenleyicilerin "batmayacak kadar büyük" olduğu kabul edilen büyük finansal kuruluşları küçük parçalara ayırmayı düşünmesi gerektiğini dile getirmiştir (McKee and Lanman, 2009). Greenspan’a göre bu bankalar kendilerinin düşük maliyetli borçlanmalarını sağlayan örtülü bir desteğe sahiptir çünkü borç verenler, yükümlülüklerini garantiye almak için kamunun daima müdahale edeceğine inanmaktadır.

ABD'de finansal krizin olumsuz etkilerinin giderilmesi, batmayacak kadar büyük uygulamasının sonlandırılması finansal hesap verilebilirliğin ve şaffaflı̆̆ geliştirilmesi suretiyle 
finansal istikrarın sağlanması amacıyla ABD Kongresi tarafindan Temmuz 2010'da the Dodd-Frank Wall Street Reform and Consumer Protection Act (kısa adiyla the Dodd-Frank Act) yürürlüğe konmuştur. Bu düzenleme ile Financial Stability Oversight Council (FSOC) oluşturulmuştur. Finansal istikrarın sağlanması için risklerin tespit edilmesi ve finansal sistemin istikrarına yönelik tehditlerin ortadan kaldırılması, piyasalardaki katılımcıların herhangi bir başarısızlık durumunda Hükümet tarafından kurtarılacağına dair beklentilerinin ortadan kaldırılması suretiyle piyasa disiplininin sağlanması ve finansal piyasaların izlenmesi Financial Stability Oversight Council'in görevleri arasında yer almaktadır (Dodd-Frank Wall Street Reform and Consumer Protection Act, 2010).

\section{Birleşik Krallık (UK)}

Eylül 2008'de; Lehman'ın iflası büyük kuruluşların batmayacak kadar büyük olduğuna dair güveni sarsmıştır. AIG’nin kredi notunu düşürülmesi kredilerin geri çağrılmasını tetiklemiş ve kamu tarafından kurtarılmayı gerekli bir hale getirmiştir. Kredi sorunları ve mevduat hücumları Washington Mutual, Bradford \& Bingley ve İzlanda bankalarının çöküşüne yol açmıştır (Financial Services Authority, 2009, 27).

Küresel finansal piyasalarda yaşanan karmaşayı izleyen süreçte Bradford \& Bingley, yatırımcıların ve borç verenlerin bağımsız bir kuruluş olarak varlığını sürdüreceğine olan güvenini yitirdikçe kendini giderek artan bir baskı içinde bulmuş ve Eylül 2008'de kamulaştırılmıştır (Bank of England, 2008, 1).

Northern Rock 2007 yılının ikinci yarısında finansal piyasalarda giderek artan karışıklıktan etkilenmiş ve bu durum onun faaliyetlerini fonlama olanaklarını olumsuz yönde etkilemiştir. $\mathrm{Bu}$ durum bankayı desteklemek için hükümet müdahalesine yol açmıştır (House of Commons Treasury Committee, 2009, 45). 17 Şubat 2008'de Hazine, Northern Rock’ın kamulaştırılabileceğini açıklamıştır. 21 Şubat’ta hükümete bankaları kamulaştırmak için geçici güç veren yasal düzenleme kabul edilmiştir. Bunu takip eden gün ise Northern Rock kamulaştırılmıştır (HM Treasury, 2012, 19).

8 Ekim 2008'de Hazine tarafından yapılan basın açıklamasına göre Hükümet, finansal istikrarı sağlamak ve tasarruf sahiplerini, mevduat sahiplerini işletmeleri ve borçluları korumak için özel ve kapsamlı tedbirlerin alınacağını duyurmuştur. Bu olağanüstü piyasa koşullarının olduğu dönemde Bank of England'ın da bankacılık sisteminin yeterli likiditeye ulaşabilmesini sağlamak için ne gerekiyorsa yapacağını açıklamıştır. En az 2 milyar £ bankalar için özel likidite planı dahilinde hazır olacaktır. Yine aynı basın açıklamasına göre hükümet destekli bir yeniden sermayelendirme planında yer alacak önde gelen banka ve en büyük yapı tasarruf ve kredi birlikleri (building society) şunlardır (HM Treasury, 2008):

\footnotetext{
Abbey

- Barclays

- HBOS

- HSBC Bank plc

- Lloyds TSB
} 
- $\quad$ Nationwide Building Society

- Royal Bank of Scotland

- Standard Chartered

Halifax Bank of Scotland (HBOS), Lloyds TSB ve Royal Bank of Scotland (RBS)'a hükümet tarafından kaynak aktarılmıştır.

Bank of England, finansal sistemin genelinde yayılan güven kaybını önleyebilmek için zor durumdaki finansal kuruluşlar için son başvuru mercii olarak 2008 Sonbaharında RBS ve HBOS’a Acil Likidite Yardımı (Emergency Liquidity Assistance-ELA) sağlamıştır (bank of England, 2009, 1).

Bank Recapitalisation Fund Royal Bank of Scotland ve Lloyds TSB ile HBOS'un birleşmesinden oluşan Lloyds Banking Group̉a vergi mükellefleri tarafından finanse edilen 37 milyar £’luk sermaye enjekte etmiştir (Chote vd., 2009, 94).

2012'de Federal Deposit Insurance Corporation ve Bank of England tarafindan birlikte yayınlanan belgede $\mathrm{ABD}$ ve Birleşik Krallık'taki yetkili otoritelerin batmayacak kadar büyük olarak algılanan sistemik öneme sahip kuruluşlara yönelik ortak yaklaşımları açıklanarak bu otoritelerin çok büyük finansal kuruluşlara yönelik olarak çözümleme stratejileri geliştirmek için birlikte çalıştıklarına ve bu stratejilerin büyük ve karmaşık sınır ötesi firmaları finansal istikrarı tehdit etmeksizin ve kamu fonlarını riske atmaksızın çözümlemek için tasarlandıklarına değinilmiştir (Bank of England, 2012, i).

Kriz öncesi düzenlemelerin başarısız olması, Birleşik Krallık'ta yetkili otoritelerin mevcut düzenleyici yapıda geniş çaplı değişiklikleri gündeme getirmesine yol açmış ve Nisan 2013’te yürürlüğe giren "Finansal Hizmetler Yasası" kapsamında yeni bir düzenleyici yapıya geçilmiştir. $\mathrm{Bu}$ yasa ile Birleşik Krallık'ta finansal piyasaların düzenlenmesinden sorumlu olan Financial Services Authority (FSA - Finansal Hizmetler Otoritesi) sona ererek yerini Bank of England'ın bir organı olacak Prudential Regulation Authority'ye (PRA) bırakmıştır. PRA, mevduat kabul eden kuruluşların, sigorta kuruluşlarının ve yatırım firmalarının mikro basiretli düzenlemesinden sorumludur. Bank of England'ın bünyesinde yer alan bir diğer kurum ise Financial Policy Commitee (FPC)'dir. FPC, finansal istikrarın sağlanması için sistemik risklerin azaltılması ya da ortadan kaldırılmasına yönelik faaliyette bulunacaktır. Financial Conduct Authority (FCA) ise Bank of England dışında yer alan ayrı bir kurum olarak, piyasaların etkin bir şekilde işlemesinden sorumludur. Bunu sağlamak için de tüketicilerin korunmasını, finansal sistemin bütünlüğünün sağlanmasını ve etkin rekabetin teşvik edilmesini amaçlamaktadır. FCA ayrıca PRA’nın gözetimi dışında kalan tüm finansal hizmet kuruluşlarının mikro basiretli düzenlemesinden sorumludur (Bank of England, 2013, 20-21-24).

\section{Ispanya}

İspanyảda finansal sistemdeki toplam varlıkların \%1'inden biraz daha fazlasına tekabül eden iki tasarruf bankası 2007 yazında başlayan uluslararası krizin de etkileriyle krize sürüklenmiştir. $\mathrm{Bu}$ bankalardan Castilla La Mancha (CCM) Mart 2009'da kurtarılmış; bir başka tasarruf bankası olan Cajasur Mayıs 2010'da İspanya Merkez Bankası̀nın kontrolüne geçmiştir (Banco De España, 2011, 5). 


\section{Almanya}

IKB: Ağustos 2007'de kısa vadeli likidite sorunlarını giderebilmek için IKB kamu ve özel bankalardan €3.5 milyar fon almıştır. Kasım 2007'de ise ikinci kurtarma paketinde 350 milyon €’luk bir ilave risk garantisi sağlanmıştır. Şubat 2008'de de 1.5 milyar €’luk bir kurtarma paketi gerekmiştir (Deutsche Bundesbank, 2009, 101-102).

Hypo Real Estate: Lehman Brothers'in çöküşünün ardından finansal yapısı bozulan Almanya’nın başlıca büyük bankalarından Hypo Real Estate (HRE)'nin iflasa doğru sürüklendiği görülmüş ve "batmayacak kadar büyülk" olarak kabul edilerek kurtarılması için müdahale edilmiştir (Parkin and Suess, 2008).

26-28 Eylül 2008 tarihleri arasında Financial Supervisory Authority (BaFin) ve Bundesbank, yükümlülüklerini yerine getiremez duruma gelen HRE ve finansal sektör temsilcileri ile bir araya gelerek HRE için bir kurtarma paketini görüşmüşlerdir. Bu görüşmelerin neticesinde 35 milyar €’luk bir kurtarma paketi kabul edilmiştir. 2-5 Ekim 2008 tarihleri arasında yapılan görüşmeler neticesinde ise Alman hükümeti, Bundesbank, BaFin ve finansal sektör tarafından likidite desteği 50 milyar €’ya çıkarılmıştır (Deutsche Bundesbank, 2009, 33).

\section{Belçika}

Küresel krizin de etkisi ile mali sıkıntılar yaşayan ve yatırımcıların güven kaybına uğrayan ve sarsılan güveni tekrar tahsis etmek için için Belçika’nın en büyük finansal hizmetler kuruluşlarından biri olan Fortis, “batmayacak kadar büyük” kabul edilerek Eylül 2008'de Belçika, Hollanda ve Lüksemburg hükümetleri tarafından 11,2 milyar €’luk bir yardım ile kurtarılmış (Van Der Starre and Louis, 2008); yine Eylül 2008'de bir başka banka Dexia, Fransa Belçika ve Lüksemburg tarafından 6.4 milyar €’luk yardım ile kurtarılmıştır (Dexia, 2008).

\section{İzlanda}

Kriz ile birlikte İzlanda’nın üç büyük ticari bankası Glitnir, Landsbanki ve Kaupthing çökmüştür.

Kaupthing Bank, Landsbanki ve Glitnir Bank, (Finansal Denetleme Kurumu (Finansal Denetleme İdaresi) (Financial Supervisory Authority) tarafından devralınmış ve Eski bankalar kendi çözüm komitelerinin gözetimine bırakılarak "Eski” ve "Yeni” bankalara ayrılmıştır. Bunu Staumur-Burdaras, the Reykjavík Savings Bank (SPRON) ve Sparisjodabanki (Icebank)’in operasyonlarının FME tarafından Mart 2009'daki kontrolünü alması takip etmiştir (The Financial Supervisory Authority, 2009, 5).

\section{SISTEMIK ÖNEME SAHIP FINANSAL KURULUŞLAR VE TÜRKIYE}

Türkiye’de finans sektörünün önemli bir kısmını küresel krizden görece az etkilenen bankacılık sektörü oluşturmaktadır. Tablo: 6 'da görülebileceği gibi, bankaların aktif büyüklüğünün finansal sektörün toplamı içindeki payı 2014 yılı itibari ile \%86'dır. 
Tablo 6. Türkiye'de Finansal Sektörün Aktif Büyüklüğü (milyon TL)

\begin{tabular}{lll}
\hline Sektör & Tutar & Toplam içindeki Pay (\%) \\
Bankalar & 1.994 .159 & 86 \\
Portföy yönetim şirketleri & 81.867 & 4 \\
Sigorta şirketleri & 79.028 & 3 \\
Gayrimenkul yatırım ortaklıkları & 41.400 & 2 \\
Emeklilik yatırım fonları & 37.771 & 2 \\
Finansal kiralama şirketleri & 32.563 & 1 \\
Faktoring şirketleri & 26.512 & 1 \\
Finansman şirketleri & 20.284 & 1 \\
Aracı kurumlar & 14.116 & 1 \\
Reasürans şirketleri & 2.004 & 0 \\
Girişim sermayesi & 769 & 0 \\
Menkul kıymet yatırım ortaklıkları & 449 & 0 \\
Toplam & $\mathbf{2 . 3 3 0 . 9 2 3}$ & $\mathbf{1 0 0}$ \\
\hline
\end{tabular}

Kaynak: TBB (2014), “Bankalarımız 2014”, https://www.tbb.org.tr/Content/Upload/Dokuman/6257/ Bankalarimiz2014.pdf, s.14, (Erişim: Temmuz 2015)

Türkiyede faaliyet gösteren banka sayısı Mart 2015 verilerine göre 51'dir. Bu bankaların 34'ü mevduat bankası, 13’ü kalkınma ve yatırım bankası, 4’ü ise katılım bankasıdır. (BDDK, 2015, 1)

Tablo 7. Türk Bankacılık Sisteminde Yoğunlaşma (Yüzde)

\begin{tabular}{|c|c|c|c|c|}
\hline & 2004 & 2012 & 2013 & 2014 \\
\hline \multicolumn{5}{|c|}{ İlk beş banka* } \\
\hline Aktif & 63 & 60 & 58 & 58 \\
\hline Mevduat & 66 & 61 & 59 & 59 \\
\hline Kredi & 65 & 56 & 56 & 56 \\
\hline \multicolumn{5}{|c|}{ İlk on banka* } \\
\hline Aktif & 87 & 87 & 86 & 85 \\
\hline Mevduat & 91 & 91 & 89 & 89 \\
\hline Kredi & 85 & 86 & 85 & 85 \\
\hline${ }^{*}$ Toplam & & & & \\
\hline
\end{tabular}

Kaynak: TBB (2014), "Bankalarımız 2014”, https://www.tbb.org.tr/Content/Upload/Dokuman/6257/ Bankalarimiz2014.pdf, s.16, (Erişim: Temmuz 2015)

Tablo: 7 verilerine göre Türkiye’de 2014 yılı itibariyle aktif büyüklüğüne göre ilk beş bankanın toplam aktifler içindeki payı \%58, mevduatlar içindeki payı \%59, krediler içindeki payı ise $\% 56$ 'dır. İlk on bankanın toplam aktifler içindeki payı \%85, mevduatlar içindeki payı \%89, krediler içindeki payı ise $\% 85$ 'tir. 
Tablo 8. 3 I.03.20I 5 İtibariyle Aktif Büyüklüklerine Göre Banka Sıralaması

\begin{tabular}{|c|c|c|c|c|}
\hline Sira & Banka Adı & $\begin{array}{l}\text { Aktif } \\
\text { Büyülklüğü } \\
\text { (Milyon TL) }\end{array}$ & Aktif Payı \%* & \multirow{8}{*}{$\begin{array}{c}\text { Büyük } \\
\text { Ölçekli } \\
\text { Bankalar }\end{array}$} \\
\hline 1 & Türkiye Cumhuriyeti Ziraat Bankası A.Ş. & 271.280 & 13,46 & \\
\hline 2 & Türkiye İş Bankası A.Ş. & 252.931 & 12,55 & \\
\hline 3 & Türkiye Garanti Bankası A.Ş. & 231.397 & 11,48 & \\
\hline 4 & Akbank T.A.Ş. & 219.188 & 10,87 & \\
\hline 5 & Yapı ve Kredi Bankası A.Ş. & 201.124 & 9,98 & \\
\hline 6 & Türkiye Vakıflar Bankası T.A.O. & 168.362 & 8,35 & \\
\hline 7 & Türkiye Halk Bankası A.Ş. & 161.273 & 8,00 & \\
\hline 8 & Finans Bank A.Ş. & 80.494 & 3,99 & \multirow{8}{*}{$\begin{array}{c}\text { Orta } \\
\text { Ölçekli } \\
\text { Bankalar }\end{array}$} \\
\hline 9 & Denizbank A.Ş. & 73.488 & 3,65 & \\
\hline 10 & Türk Ekonomi Bankası A.Ş. & 66.954 & 3,32 & \\
\hline 11 & ING Bank A.Ş. & 40.340 & 2,00 & \\
\hline 12 & Türk Eximbank & 35.847 & 1,78 & \\
\hline 13 & HSBC Bank A.Ş. & 33.581 & 1,67 & \\
\hline 14 & Odea Bank A.Ş. & 26.293 & 1,30 & \\
\hline 15 & Şekerbank T.A.Ş. & 21.549 & 1,07 & \\
\hline 16 & Türkiye Sınai Kalkınma Bankası A.Ş. & 17.277 & 0,86 & \multirow{11}{*}{$\begin{array}{l}\text { Küçük } \\
\text { Ölçekli } \\
\text { Bankalar }\end{array}$} \\
\hline 17 & İller Bankası A.Ş. & 16.635 & 0,83 & \\
\hline 18 & Alternatifbank A.Ş. & 11.786 & 0,58 & \\
\hline 19 & Anadolubank A.Ş. & 10.117 & 0,50 & \\
\hline 20 & Burgan Bank A.Ş. & 8.989 & 0,45 & \\
\hline 21 & Fibabanka A.Ş. & 8.955 & 0,44 & \\
\hline 22 & Citibank A.Ş. & 8.597 & 0,43 & \\
\hline 23 & Aktif Yatırım Bankası A.Ş. & 6.623 & 0,33 & \\
\hline 24 & İstanbul Takas ve Saklama Bankası A.Ş. & 6.150 & 0,31 & \\
\hline 25 & Turkland Bank A.Ş. & 5.117 & 0,25 & \\
\hline 26 & Türkiye Kalkınma Bankası A.Ş. & 4.037 & 0,20 & \\
\hline
\end{tabular}




\begin{tabular}{|c|c|c|c|c|}
\hline Sira & Banka Ad 1 & $\begin{array}{l}\text { Aktif } \\
\text { Büyüklüğü } \\
\text { (Milyon TL) }\end{array}$ & Aktif Payı \%* & \multirow{22}{*}{$\begin{array}{c}\text { Mikro } \\
\text { Ölçekli } \\
\text { Bankalar }\end{array}$} \\
\hline 27 & Arap Türk Bankası A.Ş. & 3.804 & 0,19 & \\
\hline 28 & Bank of Tokyo-Mitsubishi UFJ Turkey A.Ş. & 3.425 & 0,17 & \\
\hline 29 & Tekstil Bankası A.Ş. & 3.285 & 0,16 & \\
\hline 30 & The Royal Bank of Scotland Plc. & 3.180 & 0,16 & \\
\hline 31 & Intesa Sanpaolo S.p.A. & 2.420 & 0,12 & \\
\hline 32 & Deutsche Bank A.Ş. & 2.391 & 0,12 & \\
\hline 33 & Birleşik Fon Bankası A.Ş. & 2.166 & 0,11 & \\
\hline 34 & BankPozitif Kredi ve Kalkınma Bankası A.Ş. & 2.001 & 0,10 & \\
\hline 35 & Turkish Bank A.Ş. & 1.494 & 0,07 & \\
\hline 36 & Rabobank A.Ş. & 789 & 0,04 & \\
\hline 37 & Nurol Yatırım Bankası A.Ş. & 595 & 0,03 & \\
\hline 38 & Société Générale (SA) & 453 & 0,02 & \\
\hline 39 & JPMorgan Chase Bank N.A. & 386 & 0,02 & \\
\hline 40 & Bank Mellat & 325 & 0,02 & \\
\hline 41 & Pasha Yatırım Bankası A.Ş. & 247 & 0,01 & \\
\hline 42 & Merrill Lynch Yatırım Bank A.Ş. & 224 & 0,01 & \\
\hline 43 & GSD Yatırım Bankası A.Ş. & 128 & 0,01 & \\
\hline 44 & Diler Yatırım Bankası A.Ş. & 115 & 0,01 & \\
\hline 45 & Habib Bank Limited & 80 & 0,00 & \\
\hline 46 & $\begin{array}{l}\text { Standard Chartered Yatırım Bankası Türk } \\
\text { A.Ş. }\end{array}$ & 77 & 0,00 & \\
\hline 47 & Adabank A.Ş. & 51 & 0,00 & \\
\hline
\end{tabular}

*Aktif payları TBB Mart 2015 verilerinden yararlanılarak hesaplanmıștır. Toplam aktif büyüklüğü 2.016.019 milyon TL olarak alınmıştır. Yüzde değerler yaklaşık rakamları içermektedir.

Kaynak: TBB (2015), “Aktif Büyüklüklerine Göre Banka Sıralaması Mart 2015”, https://www.tbb.org.tr, Erişim: Temmuz 2015.

Aktif büyüklügü sektör toplamı içindeki payı \%5'in üzerinde olan bankalar büyük, \%1\%5 arasında olanlar orta, \%0,20-\%1 arasında olanlar küçük, \%0,20’nin altında olanlar mikro ölçekli banka olarak sınıflandırılırsa Tablo: 8’e göre katılım bankaları hariç mevduat bankaları ve kalkınma ve yatırım bankaları açısından TBB 31 Mart 2015 verilerine göre büyük ölçekli 
bankalar grubunda 7, orta ölçekli bankalar grubunda 8, küçük ölçekli banka grubunda 11, mikro ölçekli banka grubunda ise 21 banka yer almaktadır. Büyük ölçekli bankalar grubunun bankacılık sektöründeki payı \%74,7, orta ölçekli bankalar grubunun payı \%18,8, küçük ölçekli banka grubunun payı \%5,2, mikro ölçekli banka grubunun payı ise $\% 1,4$ düzeylerindedir.

Ölçek büyüklügü, sistemik öneme sahip finansal kuruluşların belirlenmesi ölçütlerindendir ve sunulan finansal hizmetlerin hacmini ve iflas halinde karşı tarafın ve müşterilerin uğrayacağı zararın büyüklüğünü yansıtması açısından önemli bir göstergedir. (BDDK, 2011, 2)

Tablo: 9'da görülebileceği gibi, Türk bankacılık sektöründe faaliyet gösteren kuruluş sayısı, Avrupa Birliği (AB) üyesi ülkelerdeki ortalama kredi kuruluşu sayısının altındadır. (BDDK, 2011, 14)

Tablo 9. Banka Sayılarının Küresel Görünümü

\begin{tabular}{|c|c|c|c|c|c|}
\hline \multicolumn{6}{|c|}{ Banka Sayısı } \\
\hline Ülkeler & 2006 & 2007 & 2008 & 2009 & 2010 \\
\hline $\mathrm{ABD}$ & 17.293 & 16.878 & 16.345 & 15.801 & 15.379 \\
\hline Çin & 19.809 & 8.876 & 5.634 & 3.858 & 3.769 \\
\hline Endonezya & 2.010 & 2.061 & 2.027 & 2.0231 & 1.957 \\
\hline Almanya & 2.050 & 2.026 & 1.989 & 1.948 & 1.919 \\
\hline Hindistan & 1.995 & 1.943 & 1.892 & 1.843 & 1.812 \\
\hline Japonya & 1.962 & 1.890 & 1.811 & 1.759 & 1.653 \\
\hline Rusya & 1.189 & 1.136 & 1.108 & 1.058 & 1.012 \\
\hline İtalya & 807 & 821 & 818 & 801 & 778 \\
\hline Fransa & 829 & 808 & 728 & 712 & 686 \\
\hline İngiltere & 394 & 396 & 391 & 389 & 380 \\
\hline Brezilya & 133 & 125 & 127 & 123 & 125 \\
\hline Kanada & 71 & 73 & 74 & 78 & 75 \\
\hline Arjantin & 74 & 69 & 69 & 68 & 66 \\
\hline Avustralya & 54 & 55 & 58 & 57 & 55 \\
\hline Güney Kore & 54 & 54 & 56 & 55 & 55 \\
\hline Türkiye & 50 & 50 & 49 & 49 & 49 \\
\hline Meksika & 37 & 46 & 49 & 47 & 47 \\
\hline Güney Afrika & 35 & 35 & 35 & 32 & 30 \\
\hline Suudi Arabistan & 19 & 21 & 23 & 23 & 23 \\
\hline
\end{tabular}

Kaynak: IMF, OECD, BIS, Ülkelerin Bankacılık Otoriteleri’nden BDDK (2011), “Bankacılıkta Yapısal Gelişmeler”, http://www.bddk.org.tr/WebSitesi/turkce/Raporlar/Bankacilikta_Yapisal_ Gelismeler/11085bygr_2011.pdf, s.14, (Erişim: Temmuz 2015). 
G20 ülkelerinin bankacılık sektörlerine ait aktif büyüklükleri Tablo 10'da karşılaştırmalı olarak yer almaktadır. Türk bankacılık sektörünün aktif büyüklüğü G-20 ülkeleri ile kıyaslandığında 2011 y1lı itibarıyla Suudi Arabistan, Meksika, Güney Afrika, Endonezya ve Arjantin’in önünde yer almaktadır ancak diğer ülkelerin gerisindedir. Aktif büyüklügü gelişim endeksine göre ise gelişmekte olan ekonomilerin bankacılık sektörlerinin aktif büyüklüğü açısından büyüme hızları gelişmiş ülkelerinkinden daha fazladır.

\section{Tablo. I0 Aktif Büyüklüğünün Küresel Görünümü}

\begin{tabular}{|c|c|c|c|c|c|c|c|c|c|c|c|c|c|c|}
\hline \multirow[b]{2}{*}{ Milyar $\epsilon$} & \multicolumn{7}{|c|}{ Aktif Büyüklüğü } & \multicolumn{7}{|c|}{ Aktif Büyüklüğü Gelişim Endeksi } \\
\hline & 2005 & 2006 & 2007 & 2008 & 2009 & 2010 & 2011 & 2005 & 2006 & 2007 & 2008 & 2009 & 2010 & 2011 \\
\hline $\mathrm{ABD}$ & 9.703 & 9.554 & 9.484 & 10.543 & 9.858 & 10.435 & 10.739 & 100 & 98 & 98 & 109 & 102 & 108 & 111 \\
\hline Almanya & 5.884 & 6.135 & 6.615 & 6.409 & 6.022 & 6.209 & 6.496 & 100 & 104 & 112 & 109 & 102 & 106 & 110 \\
\hline Arjantin & 52 & 49 & 66 & 72 & 73 & 95 & 113 & 100 & 96 & 127 & 139 & 141 & 183 & 218 \\
\hline Avustralya & 887 & 1.019 & 1.497 & 1.365 & 1.826 & 2.281 & 2.688 & 100 & 115 & 169 & 154 & 206 & 257 & 303 \\
\hline Brezilya & 650 & 788 & 799 & 871 & 1.201 & 1.535 & 1.633 & 100 & 121 & 123 & 134 & 185 & 236 & 251 \\
\hline Çin Halk C. & 2.864 & 3.084 & 3.475 & 4.645 & 5.703 & 7.646 & 9.856 & 100 & 108 & 121 & 162 & 199 & 267 & 344 \\
\hline Endonezya & 79 & 93 & 115 & 115 & 147 & 200 & 246 & 100 & 117 & 145 & 144 & 185 & 252 & 310 \\
\hline Fransa & 4.673 & 5.396 & 6.359 & 6.892 & 6.753 & 7.526 & 8.018 & 100 & 115 & 136 & 147 & 144 & 161 & 172 \\
\hline G.Afrika & 229 & 219 & 253 & 239 & 279 & 381 & 393 & 100 & 95 & 111 & 104 & 122 & 166 & 171 \\
\hline Güney Kore & 896 & 993 & 990 & 924 & 963 & 1.146 & 1.269 & 100 & 111 & 110 & 103 & 107 & 128 & 142 \\
\hline Hindistan & 501 & 595 & 753 & 767 & 908 & 1.279 & 1.469 & 100 & 119 & 150 & 153 & 181 & 255 & 293 \\
\hline Ingiltere & 4.394 & 5.500 & 7.006 & 7.291 & 7.542 & 8.115 & 8.488 & 100 & 125 & 159 & 166 & 172 & 185 & 193 \\
\hline İspanya & 2.060 & 2.421 & 2.840 & 3.079 & 3.126 & 3.114 & 3.142 & 100 & 118 & 138 & 149 & 152 & 151 & 153 \\
\hline İtalya & 2.666 & 2.989 & 3.320 & 3.405 & 3.444 & 3.701 & 3.920 & 100 & 112 & 125 & 128 & 129 & 139 & 147 \\
\hline Japonya & 5.517 & 4.691 & 4.694 & 6.361 & 6.097 & 7.382 & 7.737 & 100 & 85 & 85 & 115 & 111 & 134 & 140 \\
\hline Kanada & 1.601 & 1.598 & 1.880 & 1.865 & 2.059 & 2.316 & 2.454 & 100 & 100 & 117 & 117 & 129 & 145 & 153 \\
\hline Meksika & 176 & 179 & 186 & 261 & 258 & 324 & 332 & 100 & 101 & 106 & 148 & 147 & 184 & 189 \\
\hline Rusya & 286 & 405 & 421 & 545 & 518 & 648 & 797 & 100 & 141 & 147 & 190 & 181 & 227 & 279 \\
\hline S.Arabistan & 171 & 174 & 197 & 248 & 255 & 282 & 315 & 100 & 102 & 115 & 145 & 149 & 165 & 184 \\
\hline Türkiye & 255 & 269 & 325 & 330 & 373 & 526 & 582 & 100 & 105 & 127 & 129 & 146 & 206 & 228 \\
\hline
\end{tabular}

Kaynak: Economist Intelligence Unit’ten BDDK (2011), “Bankacılıkta Yapısal Gelişmeler”, http://www. bddk.org.tr/WebSitesi/turkce/Raporlar/Bankacilikta_Yapisal_Gelismeler/11085bygr_2011.pdf, s.19,

(Erişim: Temmuz 2015).

TCMB Mayıs 2014 Finansal İstikrar Raporu’na göre Türkiye’de küresel sistemik öneme sahip kuruluş bulunmamakla birlikte, bu kuruluşların iştirakleri faaliyet göstermektedir; ayrıca yerel sistemik öneme sahip banka belirleme metodolojisi konusunda çalışmalar devam etmektedir (TCMB, 2014, 89).

FSB tarafindan yayınlanan "2013 IMN Survey of National Progress in the Implementation of G-20/FSB Recommendations” raporuna göre Türkiye’de küresel sistemik öneme sahip finansal kuruluş olarak kabul edilebilecek bir kuruluş yoktur (Financial Stability board, 2013b, 16); ancak Türkiye'de sistemik riskler ve makro basiretli gözetime ilişkin olarak birtakım düzenlemeler yapılmaktadır. Finansal İstikrar Komitesi, Sistemik Risk Koordinasyon Komitesi (sonradan yerini Sistemik Risk Değerlendirme Grubu almıştır) ve Finansal Sektör Komisyonu’nun oluşturulması bu konuda yapılan düzenlemeler arasında yer almaktadır. 
FSB tarafından yayınlanan "2014 IMN Survey of National Progress in the Implementation of G-20/FSB Recommendations” raporunda ise Türkiye’de bankaların hakim olduğu bir finansal sistem olduğu ve menkul kıymet piyasalarında sistemik açıdan önemli kuruluş olmadığı ifade edilmektedir (Financial Stability Board, 2014c, 23).

Bankacılık Kanununun mülga 72 nci maddesi uyarınca, 14/04/2009 tarihli Finansal Sisteme İlişkin Sistemik Risk İşbirliği Protokolü çerçevesinde BDDK, Hazine Müsteşarlığı, TMSF ve TCMB'nin katılımı ile Sistemik Risk Koordinasyon Komitesi oluşturulmuştur. 2012 yılında, çevresel faktörler bağlamında ülke riski, bulaşıcılık ve sermaye hareketleri konularını ele alan Komite, sistemik risklerin izlenmesine yönelik veri ihtiyaçları üzerinde de çalışmıştır (BDDK, 2013, 50-51).

Türkiye'de 8 Haziran 2011 tarih ve 637 sayılı Kanun Hükmünde Kararname ile; Hazine Müsteşarlığının bağlı olduğu Bakanın başkanlığında, Hazine Müsteşarı ile TCMB, BDDK, SPK ve TMSF Başkanlarından oluşan ve başlıca görevleri sistemik riskin izlenmesi ve önlenmesi ile sistemik risk yönetimine ilişkin koordinasyonu sağlamak olan Finansal İstikrar Komitesi kurulmuştur. Finansal İstikrar Komitesi’nin görevleri arasında şu maddeler yer almaktadır (TCMB, 2011, 73-74):

- Finansal sistemin bütününe sirayet edebilecek sistemik risklerin belirlenmesi, izlenmesi ve bu tür risklerin azaltılması için gerekli tedbir ve politika önerilerini tespit etmek.

- $\quad$ İlgili birimlere sistemik risklerle ilgili uyarılar yapmak, uyarı ve politika önerileri ile ilgili uygulamaları takip etmek.

- İlgili kurumlar tarafından hazırlanacak sistemik risk yönetim planlarını değerlendirmek.

- Sistemik risk yönetimine ilişkin koordinasyonu sağlamak.

- Görev alanı ile ilgili olarak, kamu kurum ve kuruluşlarından her türlü veri ve bilgiyi sağlamak, kurumlar arasında politikaların ve uygulamaların koordinasyonunu sağlamak.

30/10/2012 tarihinde yürürlüğe konulan Finansal İstikrar Komitesi Sistemik Risk Değerlendirme Grubu Protokolü ile Sistemik Risk Koordinasyon Komitesinnin yerini Sistemik Risk Değerlendirme Grubu almıştır. Grup, Sistemik Risk Koordinasyon Komitesi’ne benzer şekilde, sistemik riske neden olabilecek muhtemel gelişmelerin önceden tespit edilebilmesi ve gerekli önlemlerin alınabilmesi için Kurum, Hazine Müsteşarlığı, SPK, TMSF ve TCMB arasında koordinasyon, işbirliği ve bilgi paylaşımını güçlendirmek üzere oluşturulmuştur (BDDK, 2013, 51).

\section{GENEL DEĞERLENDIRME VE SONUÇ}

Büyük bir finansal kuruluşta, sözgelimi büyük bir bankada ortaya çıkabilecek bir sorun domino etkisi ile diğerlerine de yayılabilir ve sistemin bütününü tehdit edebilir. Bu tür endişelerle yetkili otoriteler piyasalara müdahale ederek fon aktarmak ya da diğer vasıtalarla finansal kuruluşları batmaktan kurtarmayı tercih edebilmektedirler. Sistemik endişelerle büyük kuruluşların kurtarılması pek çok ülkede karşılaşılan bir durumdur. 
Bazı kuruluşların "batmayacak kadar büyük" olarak kabul edilmesi bu tür kuruluşların daha riskli davranışlarda bulunmasına yönelik bir teşvik yaratabilmektedir. Bu durum "batmayacak kadar büyük” ile ilişkili ahlaki risktir. Ahlaki risk, ilgili kuruluşun daha riskli aktivitelere girişmesine ve bu aktivitelerden kaynaklanabilecek olumsuz sonuçların tamamına kuruluşun kendinin katlanması yerine maliyetinin vergi mükelleflerinin üzerine yüklenmesine; daha küçük işletmelere karşı rekabet üstünlügü elde edilmesine ve piyasa disiplinin bozulmasına yol açmaktadır.

2007'de ortaya çıkan küresel finansal krizin boyutu ve şiddeti büyük finansal kuruluşlar ile ilişkili sistemik riskleri ön plana taşımış; sistemik açıdan önemli finansal kuruluşların finansal sisteme ve ekonominin bütününe zarar vermesinin önüne geçebilmek için karar alıcıların düzenlemeler yapma ve stratejiler oluşturma gereğini gündeme getirmiştir.

Sistemik riskin önlenebilmesi ve sistemik açıdan önemli finansal kuruluşlardan kaynaklanabilecek sorunların önüne geçilebilmesi için öncelikle sistemik riskin tanımlanabilmesi ve hangi finansal kuruluşların sistemik öneme sahip olduğunun saptanması gerekmektedir. Sistemik öneme sahip finansal kuruluşlar sadece bankalar değildir. Sigorta şirketleri, banka ve sigorta şirketleri dışındaki kuruluşlar da sistemik öneme sahip olabilmektedirler; bu nedenle, sistemik riskin belirlenmesine yönelik yapılan çalışmalar sadece banka odaklı değil; banka dışı finansal kuruluşları da kapsayacak şekilde genişletilmiştir.

Küresel krizle birlikte mevcut denetim sistemlerinin yetersiz kaldığ görülmüş ve sistemik riskin önlenmesine ve batmayacak kadar büyük sorunlarının giderilmesine yönelik olarak ülkeler farklı tedbirler alma yoluna gitmişlerdir. Ulusal ve uluslararası düzeyde yetkili otoriteler bu tür kuruluşlarla ilişkili riskleri değerlendirmek ve sistemik risk içeren kuruluşları saptayarak sistemik riskleri azaltmak için tedbirler almaya ve çözüm önerileri getirmeye çalışmaktadırlar. Finansal sistemlerin reforme edilmesi için çalışmalar yapılarak sistemik risklerin tespiti ve azaltılmasına yönelik olarak mevcut düzenleyici ve denetleyici organlar yeniden yapılandırılmakta ya da yeni düzenleyici mekanizmalar oluşturulmaktadır. ABD'de Financial Stability Oversight Council (FSOC), Birleşik Krallık'ta Nisan 2013'te oluşturulan Financial Policy Commitee (FPC), Prudential Regulation Authority (PRA) ve Financial Conduct Authority (FCA) örnek olarak gösterilebilir.

Avrupa Birliğìnde 16 Aralık 2010’da 1092/2010 Sayllı Tüzük ile European Systemic Risk Board (Avrupa Sistemik Risk Kurulu kısaca ESRB) oluşturulmuştur. ESRB, sistemik riskin önlenmesine ya da azaltılmasına katkıda bulunmak için makro basiretli gözetimden sorumludur (Official Journal of the European Union, 2010). Türkiye'de ise sistemik risklerin sistemik risklerin belirlenmesi, izlenmesi ve bu tür risklerin azaltılması için gerekli tedbir ve politika önerilerini tespit etmek üzere 8 Haziran 2011'de Finansal İstikrar Komitesi oluşturulmuştur.

Sistemik açıdan önemli finansal kuruluşlarda yaşanabilecek sorunlar sadece ulusal piyasaları değil, küresel piyasaları da tehdit edebildiği için bu tür kuruluşları ele alırken düzenleyici ve denetleyici kuruluşların uluslararası işbirliklerine gitmeleri ve ortak çözüm stratejileri oluşturmaları da önem kazanmaktadır. 
Sistemik riskin azaltılmasında banka ve diğer finansal kuruluşların aşırı riskli faaliyetlere girişmesinin önüne geçilmesi, piyasa disiplinin sağlanması ve piyasadaki oyuncuların piyasa kurallarına uymasının sağlanması için daha etkin bir denetim ve gözetim, finansal kuruluşların daha düşük maliyetle çözümlenmesine yönelik prosedürlerin geliştirilmesi ve bunun için gerekli yasal düzenlemelerin yapılması önem taşımaktadır. 


\section{Kaynaklar}

BAIR, Sheila C. (2011), “We Must Resolve to End Too Big to Fail”, FDIC Quarterly, Vol. 5, Number:2, http:// www.fdic.gov/bank/analytical/quarterly/2011_vol5_2/FDIC_Quarterly_Vol5No2_entire_v4.pdf, (Erişim: 24.01.2012).

BANCO DE ESPAÑA (2011), "Saving Banks: Development and Reform”, http://www.bde.es/f/webbde/ GAP/Secciones/SalaPrensa/InformacionInteres/ReestructuracionSectorFinanciero/Ficheros/en/ Notareformacajas20110217_IVI_en.pdf, (Erişim: 29.03.2013).

BANK OF ENGLAND (2008), "Bradford \& Bingley plc Statement by the Chancellor", http://www. bankofengland.co.uk/archive/Documents/historicpubs/news/2008/059.pdf, (Erişim: Mart 2015).

BANK OF ENGLAND (2009), "Additional information provided to the Treasury Committee by the Bank of England”, http://www.bankofengland.co.uk/publications/Documents/other/treasurycommittee/ financialstability/ela091124.pdf, (Erişim:21.03.2013).

BANK OF ENGLAND (2012), "Resolving Globally Active, Systemically Important, Financial Institutions”, A joint paper by the Federal Deposit Insurance Corporation and the Bank of England, http://www. bankofengland.co.uk/publications/Documents/news/2012/nr156.pdf, (Erişim: Mayıs 2014).

BANK OF ENGLAND (2013), “Quarterly Bulletin”, Vol. 3, No. 1., http://www.bankofengland.co.uk/ publications/Documents/quarterlybulletin/2013/qb1301.pdf, (Erişim: Nisan 2015).

BASEL COMMITTEE ON BANKING SUPERVISION (2011), "Global systemically important banks: assessment methodology and the additional loss absorbency requirement, http://www.bis.org/ publ/bcbs207.pdf, (Erişim: 21.03.2014).

BASEL COMMITTEE ON BANKING SUPERVISION, (2012), "a framework for dealing with domestic systemically important banks”, http://www.bis.org/publ/bcbs233.pdf, (Erişim: Mart 2014).

BASEL COMMITTEE ON BANKING SUPERVISION (2013), "Global systemically important banks: updated assessment methodology and the higherloss absorbency requirement", http://www.bis. org/publ/bcbs255.pdf, (Erişim: 21.02.2014).

BDDK (2011), "Bankacılıkta Yapısal Gelişmeler”, http://www.bddk.org.tr/WebSitesi/turkce/Raporlar/ Bankacilikta_Yapisal_Gelismeler/11085bygr_2011.pdf, (Erişim: Temmuz 2015).

BDDK (2013), “2012 Ylllı Faaliyet Raporu”, http://www.bddk.org.tr/websitesi/turkce/kurum_bilgileri/ yillik_raporlar/11922yfr2012internet22nisan.pdf, (Erişim: 31.03.2014).

BDDK (2015), “Türk Bankacılık Sektörü Temel Göstergeleri Mart 2015, http://www.bddk.org.tr/WebSitesi/ turkce/Raporlar/TBSGG/14114tbs_temel_gostergeler_raporu_mart_2015.pdf, (Erişim: Temmuz 2015).

BEBECHUK, Luchian (2009), "AIG Still Isn't Too Big to Fail”, http://online.wsj.com/article/ SB123751263240591203.html, (Erişim: 5 Ocak 2012)

BIS (2010), "80th Annual Report”, Basel: Bank for International Settlements, http://www.bis.org/publ/ arpdf/ar2010e.pdf, (Erişim: 15.03.2013).

BIS-IMF-FSB (2009), "Report to G20 Finance Ministers and Governors: Guidance to Assess the Systemic Importance of Financial Institutions, Markets and Instruments: Initial Considerations", http:// www.imf.org/external/np/g20/pdf/100109.pdf, (Erişim: 30.01.2012).

BOARD OF GOVERNORS OF THE FEDERAL RESERVE SYSTEM (2014), "Bear Stearns, JPMorgan Chase, and Maiden Lane LLC",http://www.federalreserve.gov/newsevents/reform_bearstearns. htm, (Erişim: Aralık 2014).

BRUNNERMEIER, Markus K. (2009), “Deciphering the Liquidity and Credit Crunch 2007-08”, Journal 
of Economic Perspectives-Volume 23, Number 1, pages 77-100, http://www.princeton. edu/ markus/research/papers/liquidity_credit_crunch.pdf, (Erişim: 05.04.2012).

Claessens, Stijn, Nichael Keen, and Ceyla Pazarbasioglu (2010), “Financial Sector Taxation: The IMF’s Report to the G-20 and Background Material", IMF Report, https://www.imf.org/external/np/ seminars/eng/2010/paris/pdf/090110.pdf, (Erişim Tarihi: Mayıs 2015).

CHOTE, Robert vd. (2009), “The IFS Green Budget: January 2009”, Institute For Financial Studies, http:// www.ifs.org.uk/comms/comm107.pdf, (Erişim: 21.03.2013).

CHOW, Julian T. S. and Jay Surti (2011), “Making Banks Safer: Can Volcker and Vickers Do It?,” IMF Working Papers 11/236, International Monetary Fund, http://www.imf.org/external/pubs/ft/ wp/2011/wp11236.pdf, (Erişim: 23.07. 2012).

DEUTSCHE BUNDESBANK (2009), "Financial Stability Review”, http://www.bundesbank.de/Redaktion/ EN/Downloads/Publications/Financial_Stability_Review/2009_financial_stability_review.pdf? blob=publicationFile, (Erişim: 04.04.2013).

DEXIA (2008), Press Release, http://www.dexia.com, (Erişim: Mayıs 2005)

DODD-FRANK WALL STREET REFORM AND CONSUMER PROTECTION ACT (2010), https://www. sec.gov/about/laws/wallstreetreform-cpa.pdf, (Erişim: Ocak 2015)

ENIS, Huberto M. and H. S. Malek (2005), "Bank risk of failure and the too-big-to-fail policy”, Economic Quarterly, Federal reserve Bank of richmond, Vol.91/2, http://www.richmondfed.org/publications/ research/economic_quarterly/2005/spring/pdf/ennismalek.pdf, (Erişim: 10.01.2012).

EUROPEAN CENTRAL BANK (2009), “The concept of systemic risk”, Financial Stability Review, http://www.ecb.europa.eu/pub/pdf/other/financialstabilityreview200912en. pdf?7e1073aa7dd961b1248c19c2fecbf696, (Erişim: 1.1.2014).

FDIC (2008), "Information for Claimants in Washington Mutual Bank", http://www.fdic.gov/news/news/ press/2008/pr08085b.html, (Erişim: 06.01.2012)

FINANCIAL SERVICES AUTHORITY (2009), “The turner Review”, http://www.fsa.gov.uk/pubs/other/ turner_review.pdf, (Erişim: 21.03.2013).

FINANCIAL STABILITY BOARD (2010), "Reducing the moral hazard posed by systemically important financial institutions”, http://www.financialstabilityboard.org/publications/r_101111a.pdf, (Erişim: 04.03.2014).

FINANCIAL STABILITY BOARD (2011), "Policy Measures to Adress Systemically Important financial Institutions", http://www.financialstabilityboard.org/publications/r_111104bb.pdf, (Erişim: 08.03.2012).

FINANCIAL STABILITY BOARD (2013a), "Global systemically important insurers (GSIIs) and the policy measures that will apply to them”, http://www.financialstabilityboard.org/publications/r_130718. pdf, (Erişim: Mart 2014)

FINANCIAL STABILITY BOARD (2013b), “2013 IMN Survey of National Progress in the Implementation of G20/FSB Recommendations”, http://www.financialstabilityboard.org/implementation monitoring/turkey_2013.pdf, (Erişim: Mart 2014).

FINANCIAL STABILITY BOARD (2014a), "2014 update of list of global systemically important insurers (G-SIIs)”, http://www.financialstabilityboard.org/wp-content/uploads/r_141106a.pdf, (Erişim: 03.03.2015).

FINANCIAL STABILITY BOARD (2014b), “2014 Update of List of Global Systemically Important Banks (G-SIBs)”, http://www.financialstabilityboard.org/wp-content/uploads/r_141106b.pdf, (Erişim: 03.03.2014). 
FINANCIAL STABILITY BOARD (2014c), "2014 IMN Survey of National Progress in the Implementation of G20/FSB Recommendations", http://www.financialstabilityboard.org/wp-content/uploads/ Turkey_2014.pdf, (Erişim: Mayıs 2015).

FINANCIAL STABILITY BOARD and IOSCO (2014), "Assessment Methodologies for Identifying Non-Bank Non-Insurer Global Systemically Important Financial Institutions Proposed High-Level Framework and Specific Methodologies", http://www.financialstabilityboard.org/ publications/r_140108.pdf (Erişim: Mart 2014).

FINANCIAL STABILITY OVERSIGHT COUNCIL (2011), "Study \& Reccomendations Regarding Concentrationlimits on Large Financial Companies", The FSOC's Report on the Concentration Limit on Large Financial Companies, http://www.treasury.gov/initiatives/Documents/ Study\%20on\%20Concentration\%20Limits\%20on\%20Large\%20Firms\%2001-17-11.pdf, (Erişim: 29.03.2012).

GOLDSTEIN, Morris and Nicolas Véron (2011), “Too big to fail: The transatlantic debate”, Peterson Institute for International Economics WP 11-2, Washington, DC., http://www.iie.com/publications/wp/ wp11-2.pdf, (Erişim: 23.01.2012).

HM TREASURY (2008), “Financial support to the banking industry”, http://webarchive.nationalarchives. gov.uk/+/http:/www.hm-treasury.gov.uk/press_100_08.htm, (Erişim: 21.03. 2013).

HM TREASURY (2012), "Review of HM Treasury's management response to the financial crisis", http:// www.hm-treasury.gov.uk/d/review_fincrisis_response_290312.pdf, (Erişim: 21.03.2013).

HOENIG, Thomas M. (2008), "Monetary Policy, Financial Markets and Regulatory Reform: A Desperately Unpopular Undertaking”, Denver, Colorado, http://www.kc.frb.org/SpeechBio/HoenigPDF/ Denver.05.06.2008.pdf, (Erişim: 19.01.2012).

HOENIG, Thomas M. (2009), “Too Big Has Failed”, http://www.kc.frb.org/speechbio/hoenigpdf/ omaha.03.06.09.pdf, (Erişim: 19.01.2012).

HOUSE OF COMMONS TREASURY COMMITTEE (2009), "Banking Crisis: dealing with the failure of the UK banks", Seventh Report of Session 2008-09, http://www.publications.parliament.uk/pa/ cm200809/cmselect/cmtreasy/416/416.pdf, (Erişim: Nisan 2015).

INTERNATIONAL ASSOCIATION OF INSURANCE SUPERVISORS (2013), "Global Systemically Important Insurers: Initial Assessment Methodology”, http://www.iaisweb.org/view/element_href. cfm?src=1/19151.pdf, (Erişim: Mart 2014).

ITO, Takatoshi (2011), "Reform of Financial Supervisory and Regulatory Regimes: What has Been Achieved and What is Still Missing", International Economic Journal, Vol. 25, No. 4, 553-569.

MCKEE, Michael, and Scott Lanman (2009), "Greenspan Says U.S. Should Consider Breaking Up Large Banks., http://www.bloomberg.com, http://www.bloomberg.com/apps/ news?pid=newsarchive\&sid=aJ8HPmNUfchg, (Erişim: 02.02.2013).

OFFICIAL JOURNAL OF THE EUROPEAN UNION (2010), “REGULATION (EU) No 1092/2010 OF THE EUROPEAN PARLIAMENT AND OF THE COUNCIL of 24 November 2010”, http://eurlex.europa.eu/legal-content/EN/TXT/?uri=CELEX:32010R1092, (Erişim: 02.03.2014).

ÖTKER-ROBE, I. vd. (2011), “The Too Important to Fail Conundrum: Impossible to Ignore and Difficult to Resolve," Staff Discussion Note 11/12, Washington, D.C., International Monetary Fund, http:// www.imf.org/external/pubs/ft/sdn/2011/sdn1112.pdf, (Erişim: 23.07.2012).

PARKIN, Brian and Oliver Suess (2008), "Hypo Real Gets EU50 Billion Government-Led Bailout (Update3)”, http://www.bloomberg.com, (Erişim: 04.04.2013)

SIGTARP (2011), “Quarterly Report to Congress., http://www.sigtarp.gov/Quarterly\%20Reports/ 
January2011_Quarterly_Report_to_Congress.pdf, (Erişim: 11.05.2012).

TBB (2014), “Bankalarımız 2014”, https://www.tbb.org.tr/Content/Upload/Dokuman/6257/ Bankalarimiz2014.pdf, (Erişim: Temmuz 2015).

TBB (2015), “Aktif Büyüklüklerine Göre Banka Sıralaması - 2015 - Mart”, https://www.tbb.org.tr, (Erişim: Temmuz 2015).

TCMB (2011), “Finansal İstikrar Raporu”, sayı:13, http://www.tcmb.gov.tr/wps/wcm/connect/9939711e8f31-498d-875a-17a37e370b8e/Fir_TamMetin13.pdf, (Erişim: Nisan 2015)

TCMB (2014), "Finansal İstikrar Raporu", sayı 8, http://www.tcmb.gov.tr/wps/wcm/connect/7671f60017d4-41df-8734-c92596399495/Fir_TamMetin18.pdf?MOD=AJPERES\&CACHEID=7671f60017d4-41df-8734-c92596399495, (Erişim: 29.09.2014).

THE FINANCIAL SUPERVISORY AUTHORITY (2009), “Annual Report 2009”, http://en.fme.is/media/ utgefid-efni/FME-Annual-Report-2009.pdf, (Erişim: 12.04.2013).

THOMSON, James B. (2010), "On Systemically Important Financial Institutions and Progressive Systemic Mitigation.” Depaul Business \& Commercial Law Journal 8, no. 2: 135-150, (Erişim: 18 Nisan 2012).

WELLS FARGO (2009), "Wells Fargo and Wachovia Merger Completed”, https://www.wellsfargo.com/ press/2009/20090101_Wachovia_Merger, (Erişim: 12.04.2012).

VAN DER STARRE, Martjin and Meera Louis (2008), "Fortis Gets EU11.2 Billion Rescue From Governments (Update2)”, http://www.bloomberg.com, (Erişim: Mayıs 2015)

ZHOU, Jianping vd. (2012), "From Bail-out to Bail-in: Mandatory Debt Restructuring of Systemic Financial Institutions”, IMF Staff Discussion Note, http://www.imf.org/external/pubs/ft/sdn/2012/sdn1203. pdf, (Erişim: 27.04.2012). 
